\title{
Pengembangan Media Pembelajaran Berbasis Sparkol Videoscribe Tema Pertumbuhan si Hijau yang Berorientasi pada Literasi Sains Siswa SMP Kelas VII
}

\author{
Ilvi Triyani", Lukman Nulhakim, Liska Berlian \\ Program Studi Pendidikan IPA, FKIP, Universitas Sultan Ageng Tirtayasa \\ *Email: triyaniilvi25@gmail.com
}

DOI: https://doi.org/10.33369/pendipa.6.1.269-277

\begin{abstract}
Sparkol Videoscribe based learning media is an intermediary in the learning process created by using the Sparkol Videoscribe application to convey learning materials to students in order to achieve a learning goal. This research aims to develop a Sparkol Videoscribe based learning media and determine the level of validity. The method used was research and development adapted from the development model according to Thiagarajan which consists of 3 stages: (1) Define; (2) Design; And (3) Development. The research instruments used in this study are interviews and validation sheets. The results of this study showed that the validity rate of Sparkol Videoscribe based on learning media the theme of the green growth oriented to science literacy, was obtained with an average score of $79.91 \%$ with a valid category. Based on the results of expert validation of the development of Sparkol Videoscribe based on learning media the theme of the green growth oriented to science literacy is valid for use in the learning process.
\end{abstract}

Keywords: Videoscribe Based Learning Media; Science Literacy; Theme of Green Growth.

\begin{abstract}
ABSTRAK
Media pembelajaran berbasis Sparkol Videoscribe merupakan suatu perantara dalam proses pembelajaran yang dibuat dengan menggunakan aplikasi Sparkol Videoscribe untuk menyampaikan materi pembelajaran kepada siswa agar tercapainya suatu tujuan pembelajaran. Penelitian ini bertujuan untuk mengembangkan media pembelajaran berbasis Sparkol Videoscribe dan mengetahui tingkat kevalidannya. Metode yang digunakan adalah penelitian dan pengembangan (Research and Development) yang diadaptasi dari model pengembangan menurut Thiagarajan yang terdiri dari 3 tahapan: (1) Define; (2) Design; dan (3) Development. Instrumen penelitian yang digunakan dalam penelitian ini adalah wawancara dan lembar validasi. Hasil penelitian ini menunjukkan bahwa tingkat kevalidan media pembelajaran berbasis Sparkol Videoscribe tema pertumbuhan si hijau yang berorientasi pada literasi sains diperoleh nilai ratarata sebesar 79,91\% dengan kategori valid. Berdasarkan hasil validasi ahli pengembangan media pembelajaran berbasis Sparkol Videoscribe tema pertumbuhan si hijau yang berorientasi pada literasi sains ini valid untuk digunakan dalam proses pembelajaran.
\end{abstract}

Kata Kunci: Media Pembelajaran berbasis Sparkol Videoscribe; Literasi Sains; Tema Pertumbuhan si Hijau. 


\section{PENDAHULUAN}

Pendidikan di abad ke-21 terlihat dari pesatnya pertumbuhan sains serta teknologi, paling utama dalam teknologi informasi dan komunikasi. Mengenai hal tersebut, ilmu pengetahuan serta teknologi (IPTEK) dapat mempengaruhi kualitas sistem pembelajaran di sekolah. Karena pembelajaran di abad ke-21 terdapat perbedaan dengan pembelajaran terdahulu yang dilakukan dengan metode serta media konvensional, sedangkan pada saat ini memerlukan inovasi-inovasi khususnya dalam penggunaan media pembelajaran (Megahantara, 2017).

Salah satu metode guna tingkatkan kualitas pembelajaran ialah dengan memanfaatkan teknologi di dalam media pembelajaran, sehingga materi dapat tersampaikan dan lebih bermakna. Salah satu pembelajaran yang terdapat di sekolah yaitu pembelajaran mengenai Ilmu Pengetahuan Alam (IPA). Dalam pembelajaran IPA terdapat peranan penting, sehingga perlu diajarkan mulai dari jenjang yang paling rendah(Wulandari, 2019).

Pembelajaran IPA pada hakikatnya merupakan suatu cara yang sistematis untuk mengetahui alam, dengan begitu pada saat mempelajari IPA tidak hanya menguasai pengetahuan (konsep, fakta ataupun prinsip) tetapi juga dapat menerapkan proses temuan (Samikwo, 2013). Tema pertumbuhan si hijau merupakan tema materi dalam pembelajaran IPA dengan mengenakan model keterpaduan connected. Tema pertumbuhan si hijau digunakan untuk memadukan atau menghubungkan beberapa bidang kajian IPA berdasarkan materi yang terdapat pada silabus SMP Kelas VII kurikulum 2013 revisi 2017. Tema pertumbuhan si hijau terdiri dari Kompetensi Dasar (KD) : KD 3.1 mengenai pengukuran, KD mengenai energi yang berada di mata pelajaran IPA kelas VII dan KD 3.9 mengenai tanah yang berada di mata pelajaran IPA kelas IX.

Menurut hasil wawancara dengan guru pembelajaran IPA kelas VII di SMPN Kota Serang, ditemukan suatu permasalahan terkait media yang sering digunakan pada kegiatan pembelajaran, yaitu buku paket, LKS, gambar (poster), power point dan charta. Ini menjadi salah satu penyebab siswa menjadi tidak aktif dalam kegiatan pembelajaran dikarenakan penggunaan media pembelajaran yang kurang menarik, sehingga siswa tidak termotivasi serta mengalami masalah dalam memahami materi. Selain itu juga diketahui bahwa literasi sains siswa di SMPN Kota serang sudah mulai diterapkan, akan tetapi masih terbilang kurang. Hal ini dikarenakan beberapa faktor yang ada pada siswa itu sendiri, yaitu ketika kegiatan pembelajaran berlangsung siswa malas untuk membaca sehingga tidak bisa memahami materi dan tidak dapat menjawab pertanyaan guru. Selain itu rendahnya kemampuan literasi sains dapat disebabkan oleh kurikulum, sumber belajar, sistem pendidikan, serta model dan metode yang digunakan dalam pembelajaran (Kurnia \& Fathurohman, 2014).

Media pembelajaran yang dapat mengatasi terkait permasalahan tersebut, yaitu salah satunya adalah media pembelajaran berbasis Sparkol Videoscribe. Sparkol Videoscribe ialah software yang dapat menciptakan suatu animasi berupa papan tulis yang dapat menjelaskan suatu konsep tertentu. Keunggulan dari Sparkol Videoscribe diantaranya yaitu memiliki animasi visual yang beragam, tampilan yang menarik, dapat membuat siswa lebih mudah memahami materi, menjelaskan serta menarik kesimpulan dalam kegiatan pembelajaran (Wulandari, 2016). Maka dari itu dengan adanya media pembelajaran berbasis Sparkol Videoscribe diharapkan siswa dapat menyerap materi IPA secara lebih utuh serta dapat menemukan pengetahuannya melalui pengamatan dan mencoba memberi makna materi yang dipelajari. Dengan begitu pembelajaran lebih menarik, efektif dan efisien, dan mampu meningkatkan kemampuan yaitu literasi sains siswa.

Berdasarkan data OECD (Organization for Economic Cooperation and Development) yang melakukan PISA (Programme International Student Assessment) bahwa aspek yang dinilai pada program ini salah satunya yaitu literasi sains. Begitupun pada pembelajaran IPA yang dicakup oleh produk kerja ilmiah, sehingga literasi sains sudah menjadi kebutuhan mutlak yang dimiliki siswa SMP dalam mengikuti pembelajaran IPA, sehingga media diperlukan untuk meningkatkan suatu kemampuan literasi sains (Wulandari, 2019) 
Dalam kurikulum 2013 diutamakan untuk menumbuhkan pola pikir dan kemampuan analisis, dengan begitu siswa dapat berpikir untuk dapat mengatasi suatu permasalahan. Hal ini juga sesuai dengan PISA yang menyatakan "literasi sains yaitu suatu kemampuan pengetahuan sains, mengidentifikasi suatu permasalahan, serta menarik kesimpulan berdasarkan bukti” (Diana, et al., 2015).

Berdasarkan penelitian dan pengembangan terdapat permasalahan yang diuraikan diantaranya: 1) Bagaimana mengembangkan media pembelajaran dengan berbasis Sparkol Videoscribe tema pertumbuhan si hijau yang berorientasi pada literasi sains siswa SMP kelas VII?; 2) Bagaimana tingkat kevalidan media pembelajaran berbasis Sparkol Videoscribe tema pertumbuhan sis hijau yang berorientasi pada literasi sains siswa SMP kelas VII?

\section{METODE PENELITIAN}

Dalam mengembangkan media pembelajaran berbasis Sparkol Videoscribe menggunakan metode penelitian serta pengembangan (Research and Development), metode ini bertujuan agar dapat menghasilkan sebuah produk serta menguji tingkat kevalidan (Sugiyono, 2014).

Penelitian ini dilaksanakan pada tahun ajaran 2021/2022 semester ganjil. Terdapat dua subjek pada penelitian ini, diantaranya subjek yang akan diteliti dan subjek yang akan diuji coba. Untuk subjek yang diteliti yaitu media pembelajaran dengan berbasis Sparkol Videoscribe yang berorientasi pada literasi sains siswa. Sementara untuk subjek yang diuji coba akan diuji oleh tiga tim ahli dari dosen FKIP UNTIRTA dengan jenjang minimal S2 dan ahli dibidangnya, serta tiga guru IPA di SMPN Kota Serang.

Desain penelitian yang digunakan yaitu model penelitian serta pengembangan 4D (FourD Models) menurut Thiagarajan (1974). Model penelitian ini terdiri dari 4 tahapan, hanya saja tahapan pada penelitian ini dibatasi sampai 3 tahapan diantaranya:

\section{Tahap Pendefinisian (Define)}

Tahapan ini adalah tahap mendasar yang memiliki tujuan menetapkan suatu permasalahan dan juga dapat menjelaskan syarat-syarat yang dibutuhkan saat mengembangkan media pembelajaran.

a. Analisis Awal-Akhir

Analisis ini memiliki tujuan untuk memunculkan suatu permasalahan dasar dalam pembelajaran IPA yang sedang dihadapi di beberapa SMP Kota Serang. Selain itu juga dilakukan analisis terkait proses-proses kegiatan pembelajaran IPA yang dilakukan dengan wawancara kepada guru IPA di SMPN Kota Serang.

b. Analisis siswa

Tahap ini bertujuan untuk menganalisis terkait karakteristik atau kualitas siswa dengan memperhatikan beberapa hal yang sesuai dengan design pengembangan dari media pembelajaran. Berdasarkan hasil analisis nantinya akan dimanfaatkan sebagai kerangka acuan dalam merancang media pembelajaran berbasis Sparkol Videoscribe.

c. Analisis Tugas

Tujuan dalam tahap ini yaitu untuk mengetahui tugas atau keterampilan lain yang dimiliki oleh siswa. Keterampilan yang dimaksud yaitu berupa kemampuan akademis dalam mata pelajaran IPA, khususnya pada tema pertumbuhan si hijau.

\section{d. Analisis Konsep}

Analisis ini bertujuan mengetahui konsep pokok, kemudian menyusunnya secara terstruktur, serta mengaitkan konsep satu dengan yang lainnya. Selain itu ini adalah salah satu tahap penting untuk memenuhi prinsip dalam mencapai kompetensi dasar (KD).

e. Spesifikasi Tujuan Pembelajaran

Merupakan perumusan hasil analisis tugas serta konsep untuk menjadi kompetensi dasar. Penyusunan tujuan pembelajaran ini merujuk pada KD serta indikator yang terdapat di kurikulum 2013 revisi 2017.

\section{Tahap Perancangan (Design)}

Tahap perancangan ini ialah tahap penyiapan rancangan awal yang bertujuan untuk merancang desain serta kebutuhan material dari media yang hendak dikembangkan, agar nantinya dapat diaplikasikan dalam kegiatan pembelajaran IPA.

$\begin{array}{lllr}\text { a. Pemilihan Media } & & \\ \text { Tahapan ini } & \text { bertujuan } & \text { untuk } \\ \text { mengidentifikasi } & \text { media } & \text { pembelajaran, yang }\end{array}$ 
disesuaikan dengan hasil analisis. Selain itu untuk menentukan media yang tepat dan juga sesuai dengan materi agar siswa terbantu dalam mencapai kompetensi dasar.

b. Pemilihan Format

Tahap ini diaplikasikan untuk membuat desain atau merancang suatu media pembelajaran yang dibuat menggunakan aplikasi Sparkol Videoscribe mengacu pada pokok materi pembelajaran serta kurikulum 2013 revisi 2017. Format yang dipilih diharapkan dapat memenuhi kriteria yang menarik, mempermudah serta dapat membantu dalam proses pembelajaran. Pemilihan format pun ditujukan pada pencapaian indikator kemampuan literasi sains siswa serta pelajaran IPA khususnya tema pertumbuhan si hijau.

c. Rancangan Awal

Tahap ini berisikan perancangan media pembelajaran yang dikembangkan menggunakan Sparkol Videoscribe. Dalam merancang media disisipkan aspek-aspek literasi sains. Pada tahap ini menjadi penentuan desain awal yang digambarkan dalam storyboard.

d. Perancangan instrumen

Instrumen dalam penelitian ini berupa angket daftar isian yang dirancang untuk mengukur tingkat kevalidan media pembelajaran Sparkol Videoscribe. Angket tersebut diantaranya terdiri dari angket validasi ahli materi, media, serta praktisi atau guru IPA, yang sebelumnya dilakukan judgmen terlebih dahulu untuk mengetahui bahwa instrumen yang dibuat sudah valid untuk digunakan.

\section{Tahap Pengembangan (Develop)}

Tahap pengembangan ini ialah tahapan menghasilkan sebuah produk berupa media pembelajaran Sparkol Videoscribe, yang kemudian akan dilakukan validasi oleh tim ahli. Validasi ini merupakan proses permintaan persetujuan terkait kesesuaian media yang dikembangkan, kemudian dinilai oleh tim ahli untuk mengetahui tingkat kevalidan produk dan nantinya akan digunakan untuk melakukan revisi produk awal. Analisis hasil dari penilaian validasi ahli dikerjakan dengan analisis deskriptif kualitatif serta kuantitatif. Untuk data kualitatif yaitu data berupa saran serta komentar yang diperoleh dari angket ahli materi, media, serta praktisi, sedangkan kuantitatif diperoleh dari skor yang terdapat dalam angket. Penskoran pada penelitian ini yang digunakan berupa skala likert (Tabel 1).

Tabel 1. Ketentuan Penskoran Tingkat Kevalidan Media Pembelajaran Berbasis Sparkol Videoscribe

\begin{tabular}{cc}
\hline Tingkat Penilaian & Skor \\
\hline Sangat Baik (SB) & 5 \\
\hline Baik (B) & 4 \\
\hline Cukup (C) & 3 \\
\hline Kurang (K) & 2 \\
\hline Sangat Kurang (SK) & 1 \\
\hline & (Riduwan, 2013)
\end{tabular}

Hasil yang diperoleh, kemudian akan dihitung nilai rata-ratanya berdasarkan kriteria penilaian, dengan tujuan untuk mendapatkan hasil akhir terkait tingkat kevalidan media pembelajaran berbasis Sparkol Videoscribe yang dikembangkan. Berikut ini adalah rumus perhitungan tingka kevalidan, yaitu:

$$
X=\frac{\sum x}{N} \times 100 \%
$$

Keterangan:

$\mathrm{X} \quad$ : Nilai rata-rata yang dicari

$\sum \mathrm{x} \quad$ : Nilai yang diperoleh

$\mathrm{N} \quad$ : Nilai Maksimal ideal

$100 \%$ : Konstanta

(Arikunto, 2016)

Untuk hasil yang sudah diperoleh dari perhitungan persentase diubah kembali menjadi bentuk nilai kualitatif. Adapun cara menentukan tingkat kevalidan media pembelajaran berbasis Sparkol Videoscribe seperti pada Tabel 2.

Tabel 2. Kategori Persentase Tingkat Kevalidan Media Pembelajaran Berbasis Sparkol Videoscribe

\begin{tabular}{cc}
\hline Persentase (\%) & Kategori \\
\hline $81 \%-100 \%$ & Sangat Valid \\
\hline $61 \%-80 \%$ & Valid \\
\hline $41 \%-60 \%$ & Cukup Valid \\
\hline $21 \%-40 \%$ & Kurang Valid \\
\hline$<20 \%$ & Sangat Kurang Valid \\
\hline & (Riduwan, 2013)
\end{tabular}




\section{HASIL DAN PEMBAHASAN}

Penelitian ini memiliki tujuan yaitu mengembangkan sebuah media pembelajaran dengan berbasis Sparkol Videoscribe tema pertumbuhan si hijau yang berorientasi pada literasi sains siswa SMP kelas VII. Penelitian ini dirancang dan dikembangkan menurut model penelitian dan pengembangan (Research and Development) 4D (Four-D Models) Thiagarajan yang dibatasi menjadi tahap pendefinisian (Define), perancangan (Design), dan pengembangan (Develop).

Tahap pendefinisian atau define, merupakan tahap awal yang harus dilakukan dalam merancang media yang terdiri dari tahap analisis awal-akhir, analisis tugas, analisis siswa, analisis konsep, dan spesifikasi tujuan pembelajaran.

Tahap perancangan atau design ialah tahap penyiapan rancangan awal yang terdiri dari beberapa tahapan yaitu pemilihan media, selain itu pemilihan format, rancangan awal yang digambarkan dengan storyboard dan perancangan instrumen penilaian.

Tahap pengembangan atau develop merupakan tahapan menghasilkan sebuah media pembelajaran berbasis Sparkol Videoscribe, kemudian setelah itu akan dinilai tim ahli/validator yang disebut dengan tahap validasi. Dengan begitu nantinya akan diperoleh penilaian baik dari segi materi dan juga media. Kemudian nantinya akan dijadikan acuan dalam perbaikan produk atau tahap revisi. Penilaian dilakukan oleh tim ahli yang terdiri dari dosen FKIP UNTIRTA dan guru IPA SMP di Kota Serang. Dalam hal ini "Media pembelajaran dapat dikatakan valid apabila hasilnya sesuai dengan kriterium" (Arikunto, 2016). Berikut merupakan hasil dari seluruh penilaian tim ahli/validator:

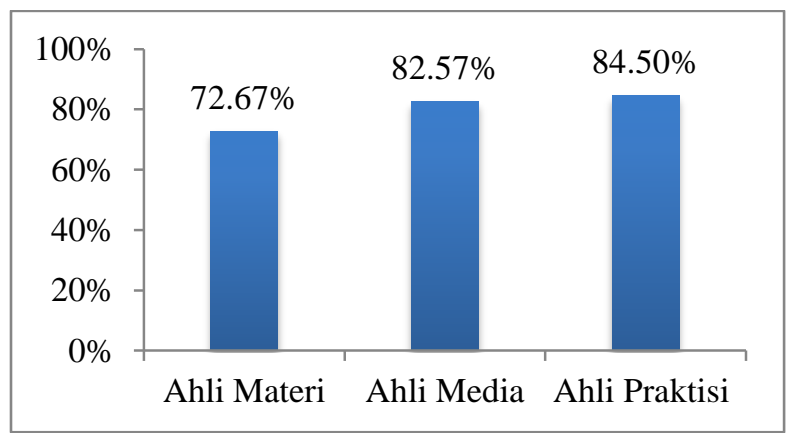

Gambar 1. Rekapitulasi Hasil Validasi Berdasarkan Tim Ahli
Berdasarkan Gambar 1 dapat diketahui bahwa hasil validasi ahli materi mendapatkan nilai dengan rata-rata $72,67 \%$ pada kategori valid. Untuk validasi ahli media mendapat nilai ratarata $82,57 \%$ dengan kategori sangat valid. Selanjutnya untuk validasi ahli praktisi mendapat nilai rata-rata $84,50 \%$ dengan kategori sangat valid.

\section{Validasi Ahli Materi}

Validasi materi merupakan tahapan pemberian penilaian terkait materi yang tercantum dalam media pembelajaran berbasis Sparkol Videoscribe yang dikembangkan berdasarkan aspek pada kisi-kisi lembar validasi ahli materi. Validator dalam penelitian ini merupakan dosen FKIP UNTIRTA yang berkualifikasi S2 dan merupakan seorang yang kompeten dalam bidang IPA. Hasil dari validasi ahli materi yaitu sebagai berikut:

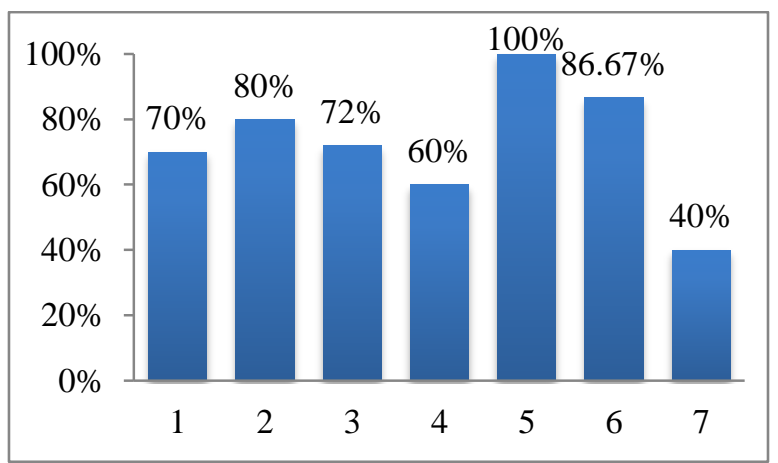

Gambar 2. Hasil Penilaian Tingkat Kevalidan oleh Ahli Materi

Keterangan: 1) Kesesuaian materi dengan KI, $\mathrm{KD}$, dan indikator pembelajaran; 2) Keakuratan materi; 3) Ketepatan materi dengan pendukung pembelajaran; 4) Kejelasan penyajian materi; 5) Penggunaan bahasa yang lugas; 6) Penggunaan bahasa sesuai dengan tingkat siswa SMP; 7)

Kesesuaian aspek literasi sains.

Pada Gambar 2 terkait hasil penilaian tingkat kevalidan yang dilakukan ahli materi terhadap media pembelajaran Sparkol Videoscribe didasarkan pada aspek yang terdiri dari beberapa indikator. Untuk aspek kelayakan isi terdiri dari kesesuaian materi dengan $\mathrm{KI}, \mathrm{KD}$, dan indikator pembelajaran, keakuratan materi serta ketepatan materi dengan pendukung pembelajaran. Untuk aspek penyajian terdiri dari kejelasan penyajian materi. Untuk aspek bahasa 
terdiri dari indikator penggunaan bahasa yang lugas dan penggunaan bahasa sesuai tingkat siswa SMP, serta aspek literasi sains terdiri dari kesesuaian aspek literasi sains. Dimana hasil penilaian yaitu diperoleh nilai dengan rata rata $72,67 \%$ pada kategori valid.

Aspek kelayakan isi meliputi kesesuaian materi dengan KI, KD, serta indikator pembelajaran mendapatkan nilai $70 \%$ dengan kategori valid, keakuratan materi mendapatkan nilai $80 \%$ dengan kategori valid ketepatan materi dengan pendukung pembelajaran mendapatkan nilai $72 \%$ dengan kategori valid. Hal ini dikarenakan menurut ahli materi terkait KI, KD, indikator pembelajaran, keakuratan serta ketepatan materi dengan tingkat berpikir kognitif pada siswa sudah sesuai. Hal ini didukung oleh Wulandari \& Purwanto (2017) yang menyatakan bahwa sesuainya KI, KD, dan tujuan pembelajaran serta materi sesuai kognitif siswa. Menurut ahli materi pada bagian ini perlu adanya perbaikan terkait indikator pembelajaran yang tersusun secara sistematis mulai dari hal sederhana sampai yang kompleks, serta disesuaikan kembali dengan model keterpaduan connected.

Aspek penyajian terdiri dari kejelasan penyajian materi mendapatkan nilai $72 \%$ kategori valid. Dalam hal ini membuktikan bahwa sistematika penyajian terkait materi sudah konsisten tetapi masih perlu ditambahkan peta konsep untuk memperjelas gagasan pokok.

Aspek bahasa terdiri dari penggunaan bahasa yang lugas mendapatkan nilai $100 \%$ dengan kategori sangat valid, untuk penggunaan bahasa sesuai dengan tingkat siswa SMP mendapatkan nilai $86,67 \%$ pada kategori sangat valid. Diketahui bahwa indikator ini memiliki nilai tertinggi, Dikarenakan dalam penggunaan bahasa sudah sesuai serta mudah untuk dipahami. Hal ini pun didukung oleh Depdiknas (2011) yang menyatakan kalimat yang disusun secara sederhana dapat menyampaikan suatu materi secara jelas dengan media yang baik.

Aspek literasi sains terdiri dari kesesuaian aspek literasi sains mendapatkan nilai $40 \%$ dengan kategori kurang valid. Menurut ahli materi literasi sains yang tercantum dalam media sudah cukup akan tetapi masih bisa untuk lebih diliterasi sains kan lagi, selain itu hal ini juga dikarenakan aspek literasi sains yang terdapat di dalam media masih belum mencakup dimensi literasi berdasarkan OECD secara keseluruhan,. Dikarenakan masih didominasi dengan aspek pengetahuan, dimana dalam mengembangkan produk masih menggunakan metode ceramah sehingga materi yang disajikan lebih dominan dibandingkan dengan aspek yang lain. Hal ini selaras dengan Yulianti \& Rusilowati (2014) bahwa dalam suatu bahan ajar mengenai literasi sains, aspek pengetahuan sains selalu lebih dominan jika dibandingkan tiga aspek lainnya.

\section{Validasi Ahli Media}

Validasi media merupakan tahapan pemberian penilaian terkait media pembelajaran dengan berbasis Sparkol Videoscribe yang dikembangkan berdasarkan aspek pada kisi-kisi lembar validasi ahli media. Validator dalam penelitian ini merupakan dosen FKIP UNTIRTA yang berkualifikasi S2 dan merupakan seorang yang kompeten dalam bidang berbasis multimedia. Hasil dari validasi ahli media yaitu sebagai berikut:

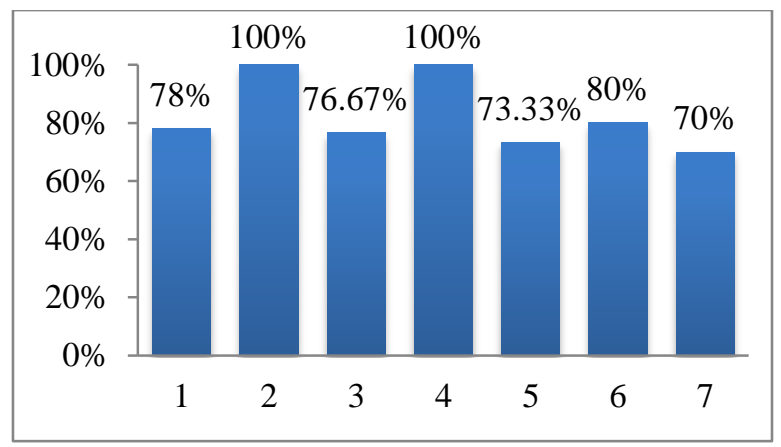

Gambar 3. Hasil Penilaian Tingkat Kevalidan oleh Ahli Media

Keterangan: 1) Desain media; 2) Tampilan pembuka; 3) Tampilan inti; 4) Tampilan penutup; 5) Kualitas penggunaan Bahasa; 6) Kesesuaian penempatan kalimat; dan 7) Tata letak

Pada Gambar 3 hasil terkait penilaian tingkat kevalidan yang dilakukan ahli media terhadap media pembelajaran yang menggunakan aplikasi Sparkol Videoscribe berdasarkan aspek yang terdiri dari beberapa indikator. Untuk aspek grafik terdiri dari desain media pembelajaran Sparkol Videoscribe. Untuk aspek penyajian terdiri atas tampilan pembuka, inti, dan penutup. Untuk aspek bahasa terdiri dari kualitas 
penggunaan bahasa dan kesesuaian penempatan kalimat. Dan untuk aspek layout media terdiri dari tata letak. Dimana hasil penilaian yaitu diperoleh nilai dengan rata rata $82,57 \%$ kategori sangat valid.

Aspek grafik terdiri dari desain media pembelajaran Sparkol Videoscribe mendapatkan nilai $78 \%$ dengan kategori valid, hal ini dikarenakan menurut ahli materi desain atau tampilan dalam media ini menarik, jenis serta ukuran pada huruf yang digunakan sudah sesuai serta memudahkan siswa untuk membaca, dan juga ketepatan serta keseimbangan pemilihan warna baik pada teks, gambar maupun background membuat media menjadi lebih menarik. Hal ini selaras dengan Wulandari (2016) yang menyatakan media berbasis Sparkol Videoscribe dapat memberi keterbacaan terhadap siswa karena dikemas dengan suatu konten menarik, sehingga penentuan teks ataupun lainnya harus disesuaikan pada jenis serta ukuran yang mampu dibaca oleh siswa.

Aspek penyajian terdiri dari tampilan, pembuka mendapatkan nilai $100 \%$ dengan kategori sangat valid, tampilan inti mendapatkan nilai 76,67\% dengan kategori valid, dan tampilan penutup didapatkan nilai $100 \%$ pada kategori sangat valid. Dalam penilaian menunjukkan terkait tampilan pada media yang dikembangkan sudah sistematis dan juga sesuai.

Aspek bahasa terdiri dari kualitas penggunaan bahasa mendapatkan nilai $73,33 \%$ dengan kategori valid dan kesesuaian penempatan kalimat mendapatkan nilai $80 \%$ dengan kategori valid. Ini dikarenakan penulisan serta bahasa yang digunakan sesuai EYD dan KBBI. Dan untuk aspek layout media terdiri dari tata letak mendapatkan nilai $70 \%$ dengan kategori valid. Dalam hal ini terkait tatal etak judul, gambar serta tulisan sudah sesuai, meskipun terlihat sederhana namun media terlihat lebih menarik serta tidak membuat siswa merasa bosan. Hal ini didukung oleh penelitian Sanjaya (2011) menyatakan bahwa multimedia harus disusun secara sederhana untuk memudahkan dalam pengoprasiannya.

\section{Validasi Ahli Praktisi}

Validasi praktisi merupakan tahap pemberian penilaian terkait materi serta media berbasis Sparkol Videoscribe. Validator dalam penelitian ini merupakan guru IPA tingkat SMP kelas VII di Kota Serang yang terdiri dari ahli praktisi I, ahli praktisi II, dan ahli praktisi III. Hasil dari validasi ahli praktisi terkait media pembelajaran berbasis Sparkol Videoscribe yaitu sebagai berikut:

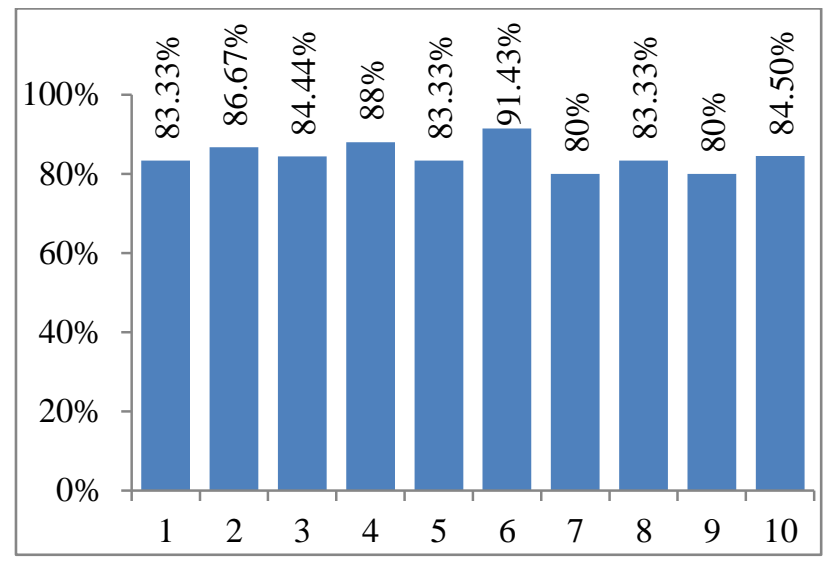

Gambar 4. Hasil Rata-Rata Penilaian Tingkat Kevalidan oleh Ahli Praktisi

Keterangan: 1) Desain media; 2) Kesesuaian materi; 3) Keakuratan materi; 4) Ketepatan materi; 5) Kejelasan penyajian materi; 6)

Kejelasan tampilan pembuka, inti, penutup; 7)

Kualitas penggunaan bahasa; 8) Kesesuaian penempatan kalimat; dan 9) Kesesuaian aspek literasi sains

Pada Gambar 4 merupakan hasil penilaian yang dilakukan oleh ahli praktisi I, praktisi II, dan praktisi III yang sudah dirata-ratakan berdasarkan indikator. Untuk hasil penilaian diperoleh nilai dengan rata-rata yaitu $84,50 \%$ yang merupakan kategori sangat valid.

Pada aspek grafik terdiri dari desain media pembelajaran Sparkol Videoscribe mendapatkan nilai rata-rata $83,33 \%$ kategori sangat valid. Untuk aspek kelayakan isi terdiri dari indikator kesesuaian materi mendapatkan nilai rata-rata $86,67 \%$, keakuratan materi mendapatkan nilai rata-rata $84,44 \%$, serta ketepatan materi didapatkan nilai rata-rata $88 \%$, sehingga seluruh indikator memiliki kategori sangat valid. Untuk aspek kelayakan penyajian terdiri dari kejelasan penyajian materi mendapatkan nilai rata rata 83,33\% dan kejelasan tampilan pembuka, inti, dan penutup mendapatkan nilai rata-rata $91,43 \%$ sehingga kedua indikator tersebut memiliki kategori sangat valid. Selain itu aspek bahasa 
terdiri dari kualitas penggunaan bahasa didapatkan nilai dengan rata-rata $80 \%$ dalam kategori valid serta kesesuaian penempatan kalimat mendapat nilai rata-rata $83,33 \%$ pada kategori sangat valid. Serta pada aspek literasi sains terkait kesesuaian aspek literasi sains dengan tampilan materi mendapatkan nilai dengan rata-rata $80 \%$ kategori valid.

Berdasarkan penilaian yang diberikan oleh seluruh ahli praktisi masih perlu adanya perbaikan terkait durasi media yang terlalu cepat sehingga harus disesuaikan kembali. Hal ini selaras dengan penelitian Khairani \& Quratul Ain (2021) perlu ditambahkannya durasi waktu video, menyesuaikan dengan background dan tulisan. Selain itu tim ahli praktisi mengatakan media pembelajaran Sparkol Videoscribe ini sangat membantu dan juga mempermudah dalam kegiatan pembelajaran, selain menarik juga sudah berbasis teknologi. Dalam hal ini Nurjanah, et al (2017) menegaskan bahwa media berbasis Sparkol Videoscribe ini sangatlah cocok jika digunakan sebagai media dalam pembelajaran.

\section{KESIMPULAN}

Berdasarkan hasil penelitian dan setelah dianalisis, dapat disimpulkan bahwa pengembangan media pembelajaran berbasis Sparkol Videoscribe tema pertumbuhan si hijau yang berorientasi pada literasi sains siswa SMP kelas VII dikembangkan dengan menggunakan metode Research and Development model 4D menurut Thiagarajan (1974). Tetapi dibatasi sampai tahap 3 saja dikarenakan adanya pandemi covid. Beberapa tahapan tersebut yaitu, tahap pendefinisian (define), perancangan (design), dan pengembangan (develop). Tingkat kevalidan pada media pembelajaran berbasis Sparkol Videoscribe tema pertumbuhan si hijau yang berorientasi pada literasi sains siswa SMP kelas VII diperoleh nilai dengan rata-rata keseluruhan $79,91 \%$, sehingga termasuk dalam kategori valid.

\section{DAFTAR PUSTAKA}

Arikunto, S. (2016). Prosedur Penelitian Suatu Pendekatan Praktik. Jakarta: Rineka Cipta.
Depdiknas. (2011). Pembinaan Pendidikan Karakter Di Sekolah Menengah Pertama. Jakarta: Dirjen Dikdasmen.

Diana, S., Arif R, \& Euis S R. (2015). Profil Kemampuan Literasi Sains Siswa Sma Berdasarkan Instrumen Scientific Literacy Assessments (Sla). Makalah Seminar Nasional Xii Pendidikan Biologi Fkip Uns, 285-291.

Khairani, A., \& Quratul Ain S. (2021). Pengembangan Media Pembelajaran Menggunakan Sparkol Videoscribe Untuk Statistic Siswa Kelas Iv Sdn 104 Pekanbaru. Jurnal Pendidikan Social Dan Agama Qalamuna, Vol. 13(2) : 219-238.

Kurnia, Z., \& Fathurohman. (2014). Analisis Bahan Ajar Fisika Sma Kelas Xi Di Kecamatan Indralaya Utara Berdasarkan Kategori Literasi Sains. Jurnal Inovasi Dan Pembelajaran Fisika, Vol. 1(1) : 43-47.

Megahantara, G. S. (2017). Pengaruh Teknologi Terhadap Pendidikan Di Abad 21. Yogyakarta: Universitas Negeri Yogyakarta.

Nurjanah, F., Nazar M, \& Rusman. (2017). Pengembangan Media Animasi Menggunakan Software Videoscribe Pada Materi Minyak Bumi Kelas X Mia Man Darussalam. Jurnal Ilmiah Mahasiswa Pendidikan Kimia, Vol.2(4).

Riduwan. (2013). Skala Pengukuran VariabelVariabel Penelitian. Bandung: Alfabeta.

Samikwo, D. C. (2013). Factors Which Influence Academic Performance In Biology In Kenya : A Perspective For Global Competitiveness. International Journal of Current Research, Vol. 5(12) : 4296-4300. 
Sanjaya, W. (2011). Strategi Pembelajaran Berorientasi Standar Proses Pendidikan. Jakarta: Kencana.

Sugiyono. (2014). Metode Penelitian Kuantitatif Kualitatif Dan R\&D. Bandung: Alfabeta.

Thiagarajan, S., Semmel D S, \& Semmel M I. (1974). Instructional Development For Training Teachers Of Exceptional Children. Indiana: Indiana University Bloomington.

Wulandari, D.A. (2016). Pengembangan Media Pembelajaran Menggunakan Sparkol Videoscribe Dalam Meningkatkan Minat Belajar Pada Mata Pelajaran Ipa Terpadu Materi Cahaya Kelas Viii Smpn 1 Kerjo Ta 2015/2016. Skripsi Program Teknologi Pendidikan. Surabaya: Unesa.
Wulandari, M. P. (2019). Keefektifan Penggunaan Media Video Animasi Ipa Sd Berbasis Literasi Sains Terhadap Hasil Belajar Siswa Kelas Iv. Jurnal Pendidikan Anak Cerdas Dan Pintar (Pancar), Vol. 3(2).

Wulandari, Y., \& Purwanto W E. (2017). Kelayakan Aspek Materi Dan Media Dalam Pengembangan Buku Ajar Sastra Lama. Jurnal Penelitian Pendidikan Bahasa Dan Sastra Indonesia, Vol. 3 : 162-172.

Yulianti, T. E., \& Rusilowati A. (2014). Analisis Buku Ajar Fisika Sma Kelas Xi Berdasarkan Muatan Literasi Sains Di Kabupaten Tegal. Upej Unnes Physics Education Journal, Vol. 3(2): 68-72. 